\title{
Regulation of transfer genes of promiscuous IncP $\propto$ plasmid RK2: repression of Tra1 region transcription both by relaxosome proteins and by the Tra2 regulator TrbA
}

\author{
Malgorzata Zatyka, $†$ Grazyna Jagura-Burdzy and \\ Christopher M. Thomas
}

Author for correspondence: Chistopher M. Thomas. Tel: +4421 414 5903. Fax: +44214145925.

School of Biological Sciences, University of Birmingham, Edgbaston, Birmingham B15 2TT, UK

\begin{abstract}
The Tra1 region of broad host range IncP $\alpha$ plasmid RK2 encodes proteins essential for its promiscuous conjugative transfer and includes oriT, the site at which nicking occurs to initiate transfer replication. Unregulated expression of the Tra1 region genes would be likely to place a major burden on the host. To investigate the control of these genes the three transcriptional promoters from this region were cloned by PCR and inserted into xyIE promoter probe vectors. The strength of traJp and traKp was estimated to be six to eightfold less than the strong trfA promoter which is required for expression of genes for vegetative replication of RK2. The traG promoter was about one-tenth the strength of the other two. These promoters are not repressed by products of the central control operon of RK2. However, traJp and traKp, which are arranged as back to back divergent promoters in the orit region, are repressed by TraK which constitutes part of the relaxosome necessary for nicking at orit. A second relaxosome protein, TraJ, represses traJp. traGp is not repressed by any relaxosome proteins. All three promoters are repressed by TrbA, which is encoded at the start of the trb operon containing the rest of the transfer genes (the Tra2 region). These circuits provide: (i) an autoregulatory way of ensuring production of enough relaxosome proteins without overburdening the host; and (ii) a means of coordinating expression of both blocks of transfer genes.
\end{abstract}

Keywords: plasmid transfer, transcription, regulation, plasmid RK2, TrbA repressor

\section{INTRODUCTION}

Broad host range IncP plasmids are capable of transfer between and replication in most Gram-negative bacterial species (for reviews see Thomas \& Helinski, 1989; Guiney \& Lanka, 1989). In addition, their conjugative apparatus can promote transfer of DNA from Gram-negative bacteria to Gram-positive bacteria (Trieu-Cuot et al., 1987; Williams $e$ t al., 1990) and also to yeast (Heinemann \& Sprague, 1989; Sikorski et al., 1990). The best studied

\footnotetext{
Abbreviation: tsp, transcription start point.

†On leave of absence from the Department of Microbial Biochemistry, Institute of Biochemistry and Biophysics, Polish Academy of Sciences, Warsaw, Poland.

The GenBank accession numbers for the nucleotide sequence data reported in this paper are X54459 and $\mathbf{5 8 7 5 8 3}$.
}

IncP plasmids are the group of indistinguishable IncP $\alpha$ plasmids, RP1, RP4, RK2, R18 and R68 (Holloway \& Richmond, 1973; Thomas \& Smith, 1987) whose complete sequence has recently been compiled (Pansegrau $e t$ al., 1994). The specific plasmids used in this work are RK2 and RP4.

The genes for the conjugative apparatus of these plasmids are organized into two blocks designated Tra1, encoding tra genes, and Tra2, encoding trb genes. Analysis of the Tra1 region indicated that transfer-associated genes span a $13 \mathrm{~kb}$ region from $\mathrm{kb}$ coordinate 39.9 to 53.0 (reviewed by Guiney $\&$ Lanka, 1989). The limits of the Tra1 region essential for intraspecific Escherichia coli matings were determined by deletion analysis (Lessl $e t$ al., 1993). This tra core encompasses $5.8 \mathrm{~kb}$ including the genes traF, $-G$, $-H,-I,-J$ and $-K$ together with the oriT region. TraI, Tra J and TraK bind in the oriT region to form the relaxosome 


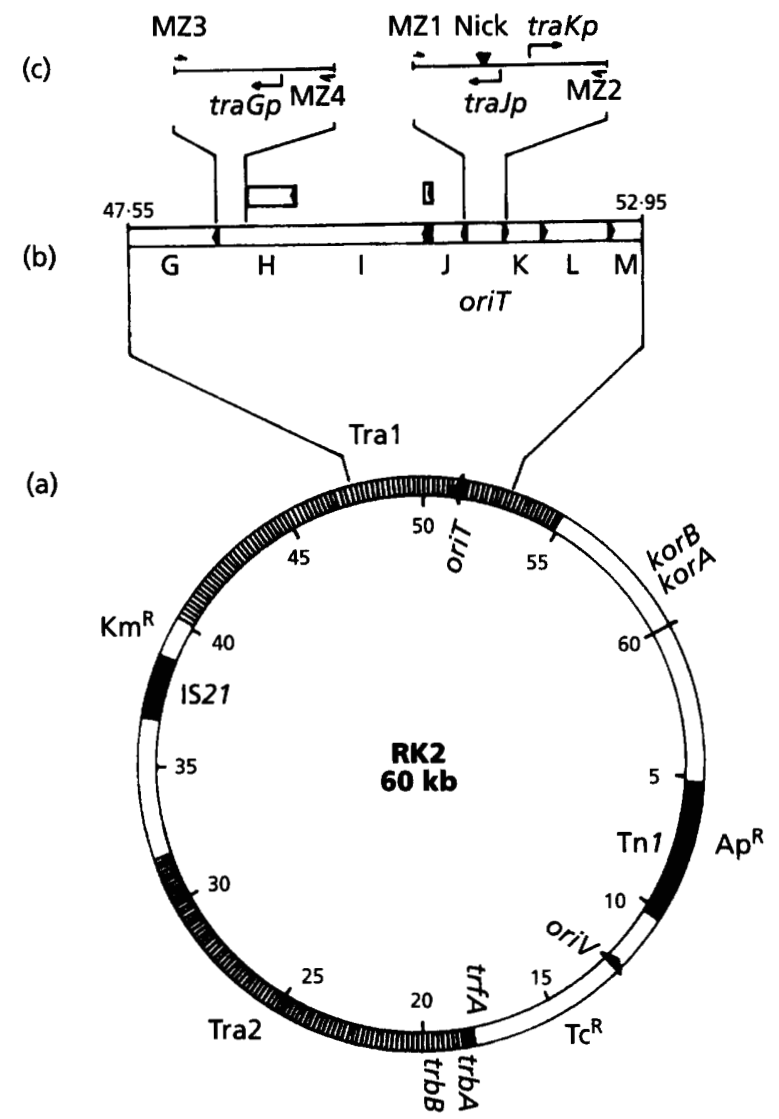

Fig. 1. Genetic organization of the Tra1 relaxosome region of RK2/RP4. (a) Map of RK2 showing the main features of the plasmid genome, including the antibiotic resistance markers, the replication functions oriV and $\operatorname{trf} A$, the two key regulators kor $A$ and kor $B$ in the central control operon and trbA in the trb operon, and the two blocks of transfer functions Tra1 and Tra2. (b) Expanded map of the Tra1 region encoding traH-traL and orit (the site where nicking occurs to initiate transfer replication) as well as parts of traG and traM. This segment is present in pMS2260. (c) Detailed location of the promoter regions cloned after $P C R$ amplification with primers $M Z 1-M Z 4$, and showing the location of the three promoters studied in this paper.

which induces the specific nick at oriT. TraF and $\mathrm{TraG}$ are thought to form a bridge to the mating pair apparatus. The other Tra1 region genes, which include $t r a C$ encoding a primase (Lanka \& Barth, 1981), are not essential for mating between $E$. coli strains although the presence of $t r a M$ significantly increases transfer efficiency (Lessl et al., 1993). Within the core region Cole et al. (1993) showed that a mutation that alters the start of $\mathrm{traH}$ has no effect on intraspecific E. coli transfer, but reduces transfer up to sevenfold for mating into some Gramnegative bacterial species.

The core trb region is located between $\mathrm{kb}$ coordinates 18.03 and $29 \cdot 26$, encompassing $11.23 \mathrm{~kb}$. The genes of this region are primarily required for mating pair formation. Nucleotide sequence revealed 12 ORFs designated $\operatorname{trb} A-L$ (Lessl et al., 1992). A series of defined trb mutants showed that at least $\operatorname{trb} B,-C,-E,-G$ and $-L$ are essential for RK2/RP4 transfer between E. coli strains. When the $\operatorname{trb} A$ ORF and the entire $\operatorname{trb} B$ regulatory region was replaced by tacp, the resulting derivative exhibited a transfer-proficient phenotype (Lessl et al., 1993). However, since TrbA has been shown to be a regulatory protein it may still have a key regulatory role when the trb operon is intact (Jagura-Burdzy et al., 1992).

In contrast to most plasmids of the F-type, the transfer frequency from bacteria which have carried IncP plasmids for a number of generations can be as high as one per donor in one hour, that is, that every bacterium can act as an efficient donor (Winans \& Walker, 1985). This has been interpreted as meaning that the IncP transfer genes are expressed constitutively. However, unregulated expression of so many genes, if they have strong promoters, would place a high metabolic burden on the bacterial host while constitutive expression from weak promoters might not give the high degree of transfer proficiency observed. Indeed, we discovered that transcription of the $\mathrm{Tra} 2$ region genes (which constitute the trb operon) from the $\operatorname{tr} b B$ promoter is repressed both by the KorB protein encoded in the central control operon (Shingler \& Thomas 1984a; Motallebi-Veshareh et al., 1992; Thomson et al., 1992) and by the TrbA protein encoded by the ORF preceding $\operatorname{trbB}$ (Jagura-Burdzy et al., 1992).

The work described in this paper focuses on the transfer genes encoded in the Tra1 region. DNA sequence and related genetic analysis has suggested that these genes are organized as two divergent transcriptional units: $\operatorname{traJ-tra} A$ running from oriT anticlockwise on the genome and traK-traM running clockwise from oriT (Fig. 1). Promoters are proposed to be located before traG, traJ and traK (Ziegelin et al., 1991). The existence of traJp and tra $G p$ has been confirmed by cloning into an expression vector and mapping the transcription start point (Greener et al., 1992). In this paper we present the cloning of all three promoters by PCR, determination of the traKp transcription start point and analysis of their regulation by the products of a number of regions.

\section{METHODS}

Bacterial strains and plasmids. Escherichia coli $\mathrm{K} 12$ strains used were $\mathrm{C} 600 \mathrm{~K}$ (thr-1 leu-6 thi-1 lacY1 supE44 tonA2 galK3; McKenney et al., 1981) and RU2537 ( $\mathrm{F}^{+}$pro-22 met-63 rec A56 nal $A$ :: Tn1723; Shingler \& Thomas, $1984 \mathrm{~b}$; from R. Schmitt, Regensburg, Germany). Plasmids used are listed in Table 1. IncP plasmid nomenclature is as recommended by Pansegrau et al. (1994). Bacteria were grown in L broth (Kahn et al., 1979). Solid medium was obtained by addition of agar $(1.5 \% \mathrm{w} / \mathrm{v})$. Cultures were grown with shaking at $37^{\circ} \mathrm{C}$. Antibiotic resistance was selected by addition of penicillin $G\left(\operatorname{Pn}^{R}\right.$, sodium salt at $100 \mu \mathrm{g} \mathrm{ml}^{-1}$ in liquid medium and $300 \mu \mathrm{g} \mathrm{ml}^{-1}$ in solid medium), kanamycin $\left(\mathrm{Km}^{\mathrm{R}}, 50 \mu \mathrm{g} \mathrm{m} \mathrm{l}^{-1}\right)$, neomycin $\left(\mathrm{Nm}^{\mathrm{R}}\right.$, $\left.100 \mu \mathrm{g} \mathrm{ml}^{-1}\right)$, chloramphenicol $\left(\mathrm{Cm}^{\mathrm{R}}, 25 \mu \mathrm{g} \mathrm{ml}^{-1}\right)$ or strepto$\operatorname{mycin}\left(\mathrm{Sm}^{\mathrm{R}}, 30 \mu \mathrm{g} \mathrm{ml}^{-1}\right)$.

Isolation of DNA, genetic manipulation and sequencing. Plasmid DNA was prepared on both small and large scales by the method of Birnboim \& Doly (1979) and if necessary by $\mathrm{CsCl} / \mathrm{EtBr}$ equilibrium density gradient centrifugation. DNA manipulations were carried out by standard techniques 
Table 1. Plasmids used in this study

\begin{tabular}{|c|c|c|c|c|c|}
\hline Plasmid & $\begin{array}{l}\text { Size } \\
(\mathbf{k b})\end{array}$ & Replicon & Selective marker & Other properties & Reference \\
\hline pBR322 & $4 \cdot 36$ & pMB1 & $\mathrm{Pn}^{\mathrm{R}} \mathrm{Tc}^{\mathrm{R}}$ & No RK2 sequence & $\begin{array}{l}\text { Bolivar et al. } \\
\text { (1977) }\end{array}$ \\
\hline pGBT30 & $6 \cdot 3$ & pMB1 & $\mathrm{Pn}^{\mathrm{R}}$ & $\operatorname{lac} I^{\mathrm{a}} \operatorname{tac} p$ & $\begin{array}{l}\text { Jagura-Burdzy } \\
\text { et al. (1991) }\end{array}$ \\
\hline pGBT43 & $10 \cdot 1$ & pSC101 & $\mathrm{Km}^{\mathrm{R}}$ & $x y l E \mathrm{pp}^{*}$ & \\
\hline pGBT58 & $10 \cdot 35$ & pSC101 & $\mathrm{Km}^{\mathrm{R}}$ & $\operatorname{trf} A p-x y l E$ & Jagura-Burdzy \\
\hline pGBT63 & $10 \cdot 60$ & pSC101 & $\mathrm{Km}^{\mathrm{R}}$ & $\operatorname{trbBp}-x y l E$ & et al. (1992) \\
\hline pGBT80 & $4 \cdot 33$ & pMB1 & $\mathrm{Pn}^{\mathrm{R}}$ & $\operatorname{tacp}-\operatorname{trb} A$ & \\
\hline pGBT100 & 6.0 & pMB1 & $\mathrm{Pn}^{\mathrm{R}}$ & $x y l E-g a l K$ pp* & $\begin{array}{c}\text { Jagura-Burdzy \& } \\
\text { Thomas (1994) }\end{array}$ \\
\hline pMS2260 & $8 \cdot 9$ & pMB1 & $\mathrm{Pn}^{\mathrm{R}} \mathrm{Cm}^{\mathrm{R}}$ & $\mathrm{RP} 4 \cot : 47 \cdot 5-52.9$ & $\begin{array}{l}\text { Pansegrau et al. } \\
(1990)\end{array}$ \\
\hline pJF166u $\Delta 5$ & $8 \cdot 2$ & pMB1 & $\mathrm{Pn}^{\mathrm{R}}$ & tacp-traJ traH & \\
\hline pJF161n $\Delta 1$ & $6 \cdot 3$ & pMB1 & $\mathrm{Pn}^{\mathrm{R}}$ & tacp-traK traL $\ddagger$ & $\begin{array}{l}\text { Fürste et al. } \\
\text { (1989) }\end{array}$ \\
\hline pJF161n $\Delta 5$ & $6 \cdot 3$ & pMB1 & $\mathrm{Pn}^{\mathrm{R}}$ & tacp-traJ & \\
\hline pCAS50 & 36 & ColE1 & $\mathrm{Km}^{\mathrm{R}}$ & $\begin{array}{l}\mathrm{RK} 2 \cot : 28 \cdot 8-60 \cdot 1 \\
0-0.8\end{array}$ & $\begin{array}{l}\text { Smith \& Thomas } \\
\text { (1983) }\end{array}$ \\
\hline pCT132 & 22 & RK2/R6K & $\mathrm{Tc}^{\mathrm{R}} \mathrm{Km}^{\mathrm{R}} \operatorname{Trp}^{+}$ & $\begin{array}{l}\mathrm{RK} 2 \operatorname{ori} V \operatorname{trf} A \\
\quad \operatorname{kor} A\end{array}$ & $\begin{array}{l}\text { C. M. Thomas } \\
\text { (unpublished) }\end{array}$ \\
\hline $\mathrm{pCT} 132 \Delta 1$ & $14 \cdot 9$ & R6K & $\mathrm{Km}^{\mathrm{R}} \operatorname{TrpE}^{+}$ & $\begin{array}{l}\text { RK2 oriV } \\
\text { pCT132 } 13 a m H I- \\
\text { SalI }\end{array}$ & This paper \\
\hline pCT153.1 & 58 & $\mathrm{R} 6 \mathrm{~K}$ & $\mathrm{Km}^{\mathrm{R}}$ & RK2 cot: $12 \cdot 0-60 \cdot 0$ & Thomas (1981) \\
\hline pCT415 & 17 & IncQ & $\mathrm{Sm}^{\mathbf{R}}$ & RK $2 \cot : 55 \cdot 0-60 \cdot 0$ & $\begin{array}{l}\text { Thomas \& } \\
\text { Hussain (1984) }\end{array}$ \\
\hline R300B & $8 \cdot 9$ & $\operatorname{Inc} Q$ & $\mathrm{Sm}^{\mathrm{R}} \mathrm{Su}^{\mathrm{R}}$ & No RK2 sequence & Barth (1979) \\
\hline pMZT1 & $6 \cdot 4$ & pMB1 & $\mathrm{Pn}^{\mathrm{R}}$ & $\operatorname{traJp}-x y / E$ & \\
\hline pMZT2 & $6 \cdot 4$ & $\mathrm{pMB} 1$ & $\mathrm{Pn}^{\mathrm{R}}$ & $\operatorname{traK} p-x y l E$ & \\
\hline pMZT3 & $6 \cdot 4$ & pMB1 & $\mathrm{Pn}^{\mathrm{R}}$ & $\operatorname{tra} G p-x y l E$ & \\
\hline pMZT4 & $10 \cdot 5$ & pSC101 & $\mathrm{Km}^{\mathrm{R}}$ & $\operatorname{traJp}-x y l E$ & \\
\hline pMZT5 & $10 \cdot 5$ & $\mathrm{pSC} 101$ & $\mathrm{Km}^{\mathrm{R}}$ & $\operatorname{traK} p-x y / E$ & \\
\hline pMZT6 & $10 \cdot 5$ & pSC101 & $\mathrm{Km}^{\mathrm{R}}$ & $\operatorname{tra} G p-x y l E$ & \\
\hline pMZT2260 & $19 \cdot 5$ & pMB1 & $\left.\mathrm{Pn}^{\mathrm{R}} \mathrm{Cm}^{\mathrm{R}} \mathrm{Km}^{\mathrm{R}}\right)$ & & This paper \\
\hline pMZT2261 & $19 \cdot 5$ & pMB1 & $\mathrm{Pn}^{\mathrm{R}} \mathrm{Cm}^{\mathrm{R}} \mathrm{Km}^{\mathrm{R}}$ & & \\
\hline pMZT2262 & $19 \cdot 4$ & pMB1 & $\mathrm{Pn}^{\mathrm{R}} \mathrm{Cm}^{\mathrm{R}} \mathrm{Km}^{\mathrm{R}}$ & & \\
\hline pMZT2263 & $19 \cdot 5$ & pMB1 & $\mathrm{Pn}^{\mathrm{R}} \mathrm{Cm}^{\mathrm{R}} \mathrm{Km}^{\mathrm{R}}$ & Tn insertion in & \\
\hline pMZT2260.1 & $9 \cdot 5$ & pMB1 & $\mathrm{Pn}^{\mathrm{R}} \mathrm{Cm}^{\mathrm{R}}$ & & \\
\hline pMZT2261.1 & $9 \cdot 5$ & pMB1 & $\operatorname{Pn}^{\mathrm{R}} \mathrm{Cm}^{\mathrm{R}}$ & & \\
\hline pMZT2262.1 & $9 \cdot 4$ & $\mathrm{pMBI}$ & $\mathrm{Pn}^{\mathbf{R}} \mathrm{Cm}^{\mathbf{R}}$ & & \\
\hline pMZT2263.1 & $9 \cdot 5$ & pMB1 & $\mathrm{Pn}^{\mathrm{R}} \mathrm{Cm}^{\mathrm{R}}$ & & \\
\hline
\end{tabular}

* Promoter probe plasmid.

† The figures shown indicate RK2/RP4 $\mathrm{kb}$ coordinates.

$\ddagger$ This plasmid contains a truncated traL.

(Sambrook et al., 1989) using enzymes according to the supplier's instructions. Sequencing was performed by the dideoxy chain termination method (Sanger et al., 1977) using a Sequenase version $2 \mathrm{kit}$ (USB) or automatically on an Applied Biosystems 373A DNA sequencer using a dye terminator kit supplied by the manufacturers.

PCR cloning of promoter fragments. Reactions were performed by standard procedures (Mullis et al., 1986) using pCAS50 as a template (Smith \& Thomas, 1983), with parameters as follows: 5 min denaturation at $94^{\circ} \mathrm{C}$ followed by 25 rounds of temperature cycling $\left(94^{\circ} \mathrm{C}\right.$ for $15 \mathrm{~s}, 54^{\circ} \mathrm{C}$ for $30 \mathrm{~s}, 71{ }^{\circ} \mathrm{C}$ for $90 \mathrm{~s}$ ) and a final $5 \mathrm{~min}$ step at $71^{\circ} \mathrm{C}$. Routinely $10 \mathrm{pmol}$ of each primer was used with $50 \mathrm{ng}$ template and 1 unit Taq polymerase in $50 \mu \mathrm{l}$ reaction buffer as recommended by the suppliers (Northumbria Biologicals Ltd). The primers were designed to place Bam HI sites at each end of the product to facilitate insertion into promoter probe vectors containing $x y l E$ as the reporter gene. Amplified fragments were purified by electroelution, digested with $\mathrm{BamHI}$, precipitated and ligated with Bam HI-treated pGBT100 or pGBT43 promoter probe vectors. An EcoRI site located in one of each pair of PCR primers 
(a)

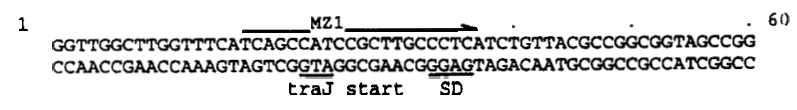

61

CCAGCCTCGCAGAGCAGGATTCCCGTTGAGCACCGCCAGGTGCGAATAAGGGACAGTGAA GGTCGGAGCGTCTCGTCCTAAGGGCAACTCGTGGCGGTCCACGCTTATTCCCTGTCACTT

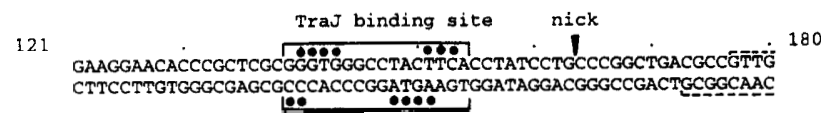

181

GATACACCAAGGAAAGTCTACACEAACCCTTTGGCAÄÄTCCTGTATATTC CTATGTGGTTCCTTTCAGATCTGCTTGGGAACCGTTTTAGGACATATAGCACGCTTTTTT trajp

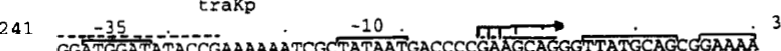
CCTACCTATATGGCTTYPTT TAGCGATATTACTGGGGCTTCGTCCCAATACGTCGCCTTTT

301 GCGCTGCTTCCCTGCTGTTTTGTGGATATCTACCGACTGGAACAGGCAAATGCAGGAA ${ }^{361}$ CGCGACGAAGGGACGACAAAACACCTTATAGATGGCTGACCTTTGTCCGTTTACGTCCTT

trak start

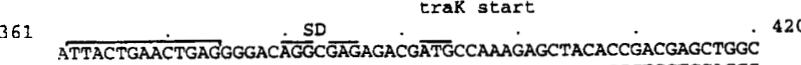
TAATGACTTGACTCCCCTGTCCGCTCTCTGCTACGGTTTCTCGATGTGGCTGCTCGACCC

421430

CGAGTGGGTT

GCTCACCCAA

(b)

TTCGGTTTTTTCGCCCGTATCTGTGGCCCCACGGCGTTGTTTCGGTTCTTCATCTACTCC AAGCCAAAAAAGCGGCATAGACACCGGGGTGCCGCAACAAAGCCAAGAAGTAGATGAGE trag start

61 TACCTCGGGTAGTTTTAAGGGAGCCTCGCGGGGTCACGGTGACGGGATCACCGATGGCGA ATGGAGCCCATCAAAATTCCCTCGGAGCGCCCAGTGCCACTGCCCTAGTGGCTACCGCP

121 GGCGCTTCATGCGTTGCACCGTGGCCTTATCGACGGGCAGCACCAGAATCTCGTCGTTTT CCGCGAAGTACGCAACGTGGCACCGGAATAGCTGCCCGTCGTGGTCTTAGAGCAGCAAA

181 CTTTCCTCAACAGGGCCAGCGCCTGGTCCTCGACGTTCCGGGTGCCTGCATAGGACAGCO GAAAGGAGTTGTCCCGGTCGCGGACCAGGAGCTGCAAGGCCCACGGACGTATCCTGTCGC

241

CACCAACATAATCAGTATATCGTGCATGCTTCGGTATATCGAAGCCGTTTAGCCGCTTTT GTGGTTGTATTAGTCATATAGCACGTACGAAGCCATATAGCTTCGGCAAATCGGCGAAAA $-10$

traGp

301

GCTCGCGCTCGGCAACATATTTCTCGGCCGCCGCGATCTGTTCGGGCTTTAGCCCTCTTC CGAGCGCGAGCCGTTGTATAAAGAGCCGGCGGCGCTAGACAAGCCCGAAATCGGGAGAAG Primer MZ4 trah stop

361

CTGGCCCAGAAACTCCCCGT GACCGGGTCTTTGAGGGGCA

Fig. 2. Sequences of promoter regions. (a) Sequence of the oriT/traJp/traKp region showing primers $\mathrm{MZ1}$ and MZ2 used for PCR, promoter locations, oriT nick site, start of traJ and traK and binding sites for TraJ and TraK. For TraK the solid line shows the core binding sites which occur at low concentration, while the dashed lines show the extended binding which occurs at higher concentration. + TraK indicates a possible alternative tsp which is only seen in the presence of TraK. (b) Sequence of the tral/traG junction region containing traGp. Confirmation/determination of the tsps is shown in Fig. 3. allowed the orientation of inserted fragment to be determined easily. The identity of the inserted fragment was confirmed by DNA sequencing.

Measurement of XyIE activity. The level of $x y l E$ expression was determined by enzymic assay of catechol 2,3-oxygenase activity using the method of Zukowski et al. (1983). One unit is defined as the amount of enzyme necessary to convert $1 \mathrm{mmol}$ substrate to product in $1 \mathrm{~min}$ under standard conditions. Protein concentration was determined by the biuret method (Gornall et al., 1949). All the assays presented in this paper were done on stationary phase cultures since the repression was more clearly observed than in exponentially growing cultures. We found significant variation in absolute activities for the same promoter-reporter gene plasmids in different experiments but the relative $x y / E$ activities between different promoters and with different combinations of repressors were reproducible within experiments. Cultures of bacteria with repressor genes under tacp control were grown in the absence of IPTG because induction was found to result in poor growth and plasmid loss.

Isolation of RNA and primer extension. Total RNA was isolated as described by Aiba et al. (1981). Standard primer extension reactions were performed with AMV reverse transcriptase (Life Sciences Inc.) using $50 \mu \mathrm{g}$ RNA and MZ1, MZ2 and MZ3 oligonucleotides (Figs 1 and 2) labelled at the $5^{\prime}$ end with $\left[\gamma^{32} \mathrm{P}\right] \mathrm{ATP}$ and polynucleotide kinase.

Transposon mutagenesis. Transposon mutants of pMS2260 with $\operatorname{Tn} 1723\left(\mathrm{Km}^{\mathrm{R}}\right)$ were isolated by transformation of RU2537 followed by selection for elevated neomycin resistance after incubation of transformant colonies at room temperature for $3 \mathrm{~d}$. The insertions were mapped by restriction analysis and DNA sequencing. For each of the insertions (pMZT2260 pMZT2263) the transposon was deleted by EcoRI digestion and religation, creating plasmids pMZT2260.1 to pMZ'T2263.1. This procedure leaves a $35 \mathrm{bp}$ insertion at the site of mutation that will cause a phase change in any ORF it disrupts.

\section{RESULTS}

\section{Cloning and mapping of Tra1 region promoters}

On the basis of DNA sequence analysis and mapping of RNA polymerase binding sites (Lanka et al., 1984, Ziegelin et al., 1991) it was predicted that the Tra1 region contains three promoters. Two of these are located very close together as back-to-back divergent promoters in the ori $T$ region and have been designated traJp and traKp. A third putative promoter was located downstream of traJp and was designated traGp. Cloning of random fragments into a promoter probe vector confirmed the existence of traJp and traGp and established the transcription start points in E. coli and a number of other species (Greener et al., 1992). To extend these studies we used PCR to generate fragments containing $\operatorname{traJ} p$ and $\operatorname{traK} p$ together and $\operatorname{traGp}$ on its own. The location and sequences of the primers used are shown in Figs 1 and 2. The promoter fragments were joined to the $x y l E$ reporter gene in both a high copy number vector (pGBT100, based on the pMB1 replicon) and a low copy number vector (pGBT43, based on the pSC101 replicon) to enable a wide range of second, compatible plasmids to be introduced into the same cell.

DNA sequencing confirmed the identity of the cloned fragments and showed that no mutations had been 


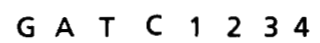
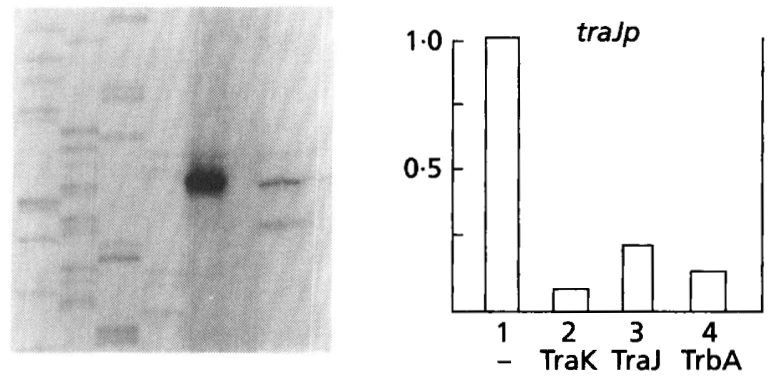

C T A $A \begin{array}{lllllllllll}1 & 2 & 3\end{array}$
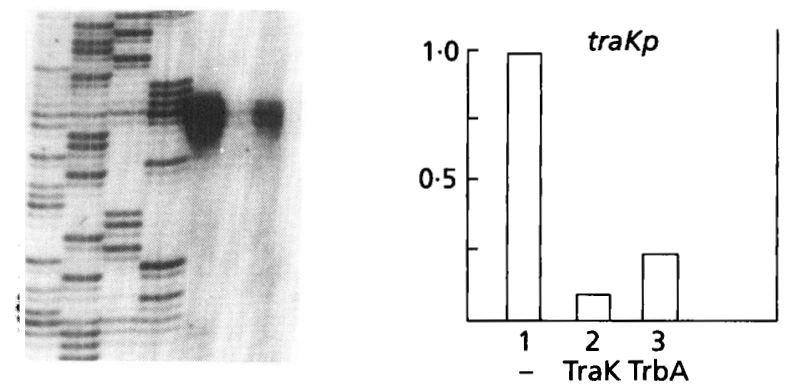

G A T C 12
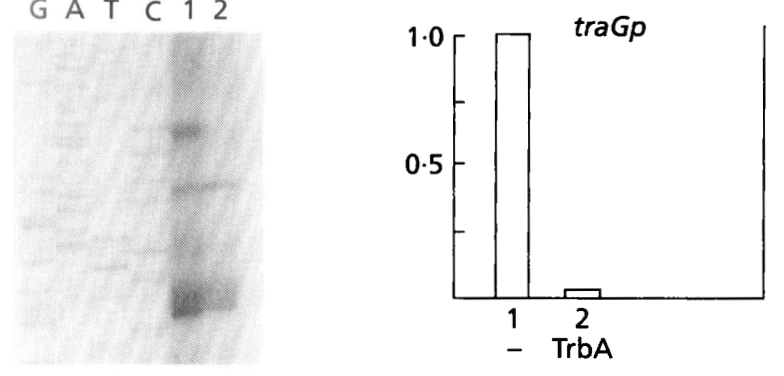

Fig. 3. Levels of mRNA initiated at traJp, traKp and traGp in the absence and presence of repressors. The abundance of $5^{\prime}$ segments of mRNA was estimated indirectly from the cDNA level synthesized by primer extension on mRNA templates isolated from different strains in which either traJp, traKp or traGp were present with pGBT30 (no RK2 genes), pJF161n $\Delta 1$ (traK), pJF166u $\Delta 5$ (traf) or pGBT80 (trbA) in trans. Radioactive images were analysed with the phosphorimager. Tracks are numbered as shown on each histogram.

introduced during amplification. Plate tests to detect $x y l E$ expression in colonies of bacteria containing the transcriptional fusions confirmed the existence of all three promoters. Quantitative assays with the low copy number derivatives showed that $\operatorname{traJp}$ (pMZT4, 0.62 XylE units) and traKp (pMZT5, 0.54 XylE units) are of similar strength and that they are one-seventh the strength of $\operatorname{trf} A p$ (the promoter for the vegetative replication operon; pGBT58, 4.00 XylE units) and one-fifth the strength of $t r b B p$ (the promoter for the trb operon encoding genes largely required for mating pair formation during transfer, pGBT63, 3.22 XylE units). traG $p$ (pMZT6, 0.06 XylE units) was about one-tenth the
Table 2. Activities of Tra1 region promoters

\begin{tabular}{|c|c|c|c|}
\hline \multirow[t]{2}{*}{ Plasmid/promoter } & \multicolumn{2}{|c|}{$\begin{array}{l}\text { XylE activity in the presence } \\
\text { of the following plasmids } \\
\text { in trans* }\end{array}$} & \multirow[t]{2}{*}{$\begin{array}{l}\text { Relative } \\
\text { activity }\end{array}$} \\
\hline & 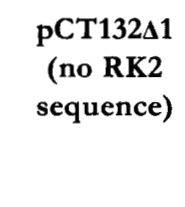 & $\begin{array}{c}\text { PCT153.1 } \\
\text { (RK2 DNA } \\
\text { from } 12 \text { to } \\
60 \mathrm{~kb} \text {; see } \\
\text { Fig. } 1 \text { ) }\end{array}$ & \\
\hline pMZT1/traJp & $5 \cdot 9 \pm 0.5$ & $0 \cdot 51 \pm 0 \cdot 13$ & 0.09 \\
\hline $\mathrm{pMZT} 2 / \operatorname{traKp}$ & $2 \cdot 7 \pm 0 \cdot 05$ & $0 \cdot 30 \pm 0 \cdot 15$ & $0 \cdot 11$ \\
\hline $\mathrm{pMZT} 3 / \operatorname{tra} G p$ & $1 \cdot 12 \pm 0 \cdot 12$ & $0 \cdot 86 \pm 0 \cdot 26$ & $0 \cdot 77$ \\
\hline
\end{tabular}

* Data from four experiments $\pm S D$. XylE activity is expressed in units as described in Methods.

T The relative activity was calculated using the activity in the presence of pCT132 1 as $1 \cdot 00$.

strength of traJp and traKp. Thus in this context traJp and traKp are medium strength promoters while tra $G p$ is weak.

Transcription start points (tsps) were determined by primer extension on mRNA extracted from bacteria carrying these recombinant plasmids. The results (Fig. 3) confirmed the transcription start point for traJp and traG $p$ as determined by Greener et al. (1992), but showed clearly a single initiation point for $\operatorname{tr} J p$ rather than initiation at a pair of successive bases. In the case of $\operatorname{traKp}$ we have mapped the multiple tsps at successive GAA residues downstream of the -10 sequence predicted by Ziegelin $e t$ al. (1991).

For $\operatorname{traGp}$ we observed shorter extended species in addition to the band which corresponds to the tsp previously mapped by Greener et al. (1992). These are probably the result of non-specific primer annealing since they are not repressed by TrbA (see below). Since TrbA reduces transcription from the cloned traGp fragment by more than $90 \%$, the sum of the bands which originate from promoters in this fragment should be repressed by this amount. The shorter species are not affected and it seems very unlikely therefore that they are related to the promoter activity being measured with the promoter-probe assays.

\section{traJp and traKp are repressed by proteins of the relaxosome region}

To determine whether or not transcription from the tra region promoters is subject to repression by the products of the RK2 genome we constructed strains in which a second plasmid carrying all or part of the RK2 genome was placed in trans to the promoter probe fusion plasmids monitoring each of the three promoters. The presence of pCT153.1 carrying a segment of the RK2 genome from coordinate 12 to $60 \mathrm{~kb}$, showed clearly that traJp and traKp are subject to repression but that $\operatorname{tra} G p$ is repressed only a little, if at all, when it is on a high copy number 
Table 3. Activity of Tra1 region promoters in the presence of central control operon genes

\begin{tabular}{|lllc|}
\hline Plasmid/promoter & $\begin{array}{c}\text { Plasmid } \\
\text { in trans }\end{array}$ & $\begin{array}{c}\text { RK2 genes in } \\
\text { trans }\end{array}$ & $\begin{array}{c}\text { XylE } \\
\text { activity* }\end{array}$ \\
\hline pMZT1/traJp & R300B & None & $2 \cdot 75 \pm 0 \cdot 05$ \\
& pCT415 & korB inc C kor $A$ & $2 \cdot 60 \pm 0 \cdot 14$ \\
pMZT2/traKp & R300B & None & $1 \cdot 45 \pm 0 \cdot 22$ \\
& pCT415 & korB incC kor $A$ & $2 \cdot 20 \pm 0 \cdot 14$ \\
pMZT3/traGp & R300B & None & $0 \cdot 25 \pm 0 \cdot 06$ \\
& pCT415 & korB inc C kor $A$ & $0 \cdot 30 \pm 0 \cdot 01$ \\
\hline
\end{tabular}

* Data from three experiments $\pm \mathrm{sD}$. XylE activity is expressed in units as described in Methods.

plasmid (Table 2). The possibility that the repression of traJp and traKp is due to the products of the central control operon was tested with plasmids R300B (no RK2 sequence) and pCT415 (kor $A$ inc $C$ korB kor $F$ kor $G$ ). This showed that the $55-60 \mathrm{~kb}$ region on the RK2 genome has no effect (Table 3 ). By contrast, when pMS2260, carrying the Tral core region, was placed in trans we observed strong repression of $t r a J p$ and $t r a K p$ but no repression of $\operatorname{traGp}$ (Table 4). We concluded therefore that traJp and traKp are repressed by relaxosome proteins but that $\operatorname{tra} G p$ is not.

\section{Identification of the relaxosome region repressors by mutagenesis and subcloning of traH to traK}

Since the region encoding oriT and the relaxosome proteins caused strong repression of traJp and $\operatorname{traK} p$, it was important to define which genes were required for this effect. We first used transposon mutagenesis of
pMS2260 to inactivate individual genes. The locations of insertions were established by restriction mapping and sequence analysis. The insertion in pMZT2260.1 is located in the vector part of pMS2260 (at bp 2385 of the pBR329 sequence as presented by Covarrubias \& Bolivar, 1982). This plasmid was used as a control and gave similar levels of repression to pMS2260 itself. The insertion in pMZT2261.1 was mapped at the penultimate codon (leucine) of traK. The $5 \mathrm{bp}$ duplicated by the insertion corresponds to coordinates $5371-5376$ according to the sequence GB_BA:ECRP4 present in GenBank under the accession numbers X54459 and S87583 (Ziegelin et al., 1991). The insertion in pMZT2263.1 occurred near the $5^{\prime}$ end of traH after the 14th amino acid codon, duplicating nucleotides 2609-2613. This insertion also disrupts traI since $\mathrm{traH}$ lies entirely within traI. In both pMZT2261.1 and pMZT2263.1 no deletions were generated by the transposon insertion. However, in the case of pMZT2262.1 the transposon caused an internal traK deletion located in its $5^{\prime}$ terminal part (after the 19th codon). This deletion removed $125 \mathrm{bp}$ between coordinates 5031 and 5156. The results (Table 4) demonstrated that inactivation of $t r a K$, while all the other relaxosome genes remained intact (pMZR2262.1), relieved completely the repression on traKp and gave an almost 10-fold derepression of traJp. The insertion in the very end of traK (pMZT2263.1) was found not to affect traK repression activity. The traH/I mutation (in pMZT2263.1) did not decrease repression of traKp and gave at most twofold derepression of traJp. Thus traK seems to be the most important gene for repression of the oriT region promoters.

To determine whether $t r a K$ can act alone as a repressor of

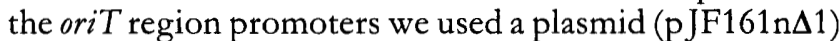
containing the traK ORF under control of the tac

Table 4. The effect of mutations in relaxosome genes on traJp, traKp and traGp expression

\begin{tabular}{|c|c|c|c|c|}
\hline Plasmid/promoter & Plasmid in trans & RK2 genes in trans & XylE activity* & $\begin{array}{c}\text { Relative } \\
\text { activity }\end{array}$ \\
\hline \multirow[t]{6}{*}{$\mathrm{pMZT} 4 /$ traJp } & pBR322 & None & $0.73 \pm 0.23$ & 1 \\
\hline & pMS2260 & $\operatorname{tra} H^{+} I^{+} J^{+} K^{+} L^{+}$ & $0.023 \pm 0.02$ & 0.03 \\
\hline & pMZT2260.1 & $\operatorname{tra} H^{+} I^{+} J^{+} K^{+} L^{+}$ & $0.016 \pm 0.01$ & $0 \cdot 02$ \\
\hline & pMZT2261.1 & $\operatorname{tra~} H^{+} I^{+} J^{+} K^{ \pm} L^{+}$ & $0.013 \pm 0.02$ & 0.02 \\
\hline & pMZT2262.1 & $\operatorname{tra} H^{+} I^{+} J^{+} K^{-} L^{+}$ & $0 \cdot 16 \pm 0 \cdot 07$ & $0 \cdot 22$ \\
\hline & pMZT2263.1 & $\operatorname{tra~} \mathrm{H}^{-} I^{+} J^{+} K^{+} L^{+}$ & $0.036 \pm 0.02$ & $0 \cdot 05$ \\
\hline \multirow[t]{6}{*}{$\mathrm{pMZT5} /$ traKp } & pBR322 & None & $1 \cdot 08 \pm 0.54$ & 1 \\
\hline & pMS2260 & $\operatorname{tra} \mathrm{H}^{+} I^{+} J^{+} K^{+} L^{+}$ & $0 \cdot 12 \pm 0 \cdot 05$ & $0 \cdot 11$ \\
\hline & pMZT2260.1 & $\operatorname{tra} H^{+} I^{+} J^{+} K^{+} L^{+}$ & $0.086 \pm 0.08$ & 0.08 \\
\hline & pMZT2261.1 & $\operatorname{tra~} H^{+} I^{+} J^{+} K^{ \pm} L^{+}$ & $0.086 \pm 0.07$ & $0 \cdot 08$ \\
\hline & pMZT2262.1 & $\operatorname{tra} H^{+} I^{+} J^{+} K^{-} L^{+}$ & $1.46 \pm 0.75$ & $1 \cdot 35$ \\
\hline & pMZT2263.1 & $\operatorname{tra} H^{-} I^{+} J^{+} K^{+} L^{+}$ & $0.045 \pm 0.09$ & 0.04 \\
\hline \multirow[t]{2}{*}{$\mathrm{pMZT6/traGp}$} & pBR322 & None & $0 \cdot 11 \pm 0 \cdot 07$ & 1 \\
\hline & pMS2260 & $\operatorname{tra} H^{+} I^{+} J^{+} K^{+} L^{+}$ & $0 \cdot 20 \pm 0 \cdot 12$ & $1 \cdot 8$ \\
\hline
\end{tabular}

* Data from three experiments $\pm S D$. XylE activity is expressed in units as described in Methods. 
Table 5. Activity of traJp and traKp in the presence of plasmids overproducing TraJ and TraK

\begin{tabular}{|c|c|c|c|c|}
\hline $\begin{array}{l}\text { Plasmid/ } \\
\text { promoter }\end{array}$ & $\begin{array}{c}\text { Plasmid in } \\
\text { trans }\end{array}$ & $\begin{array}{c}\text { RK2 } \\
\text { genes } \\
\text { in trans }\end{array}$ & $\begin{array}{c}\text { XylE } \\
\text { activity* }\end{array}$ & $\begin{array}{c}\text { Relative } \\
\text { activity }\end{array}$ \\
\hline $\mathrm{pMZT} 4 /$ traJp & $\begin{array}{l}\text { pGBT30 } \\
\text { pJF166u } \Delta 5 \\
\text { pJF161n } \Delta 1\end{array}$ & $\begin{array}{l}\text { None } \\
\text { traJ } \\
\text { traK }\end{array}$ & $\begin{array}{l}9 \cdot 80 \pm 1 \cdot 5 \\
2 \cdot 30 \pm 0 \cdot 3 \\
0 \cdot 32 \pm 0 \cdot 02\end{array}$ & $\begin{array}{l}1 \\
0 \cdot 23 \\
0 \cdot 03\end{array}$ \\
\hline pMZT5/traKp & $\begin{array}{l}\text { pGBT30 } \\
\text { pJF166u } \Delta 5 \\
\text { pJF161n } 11\end{array}$ & $\begin{array}{l}\text { None } \\
\text { traJ } \\
\text { traK }\end{array}$ & $\begin{array}{c}6 \cdot 66 \pm 1 \cdot 01 \\
\mathrm{ND} \\
0 \cdot 24 \pm 0 \cdot 05\end{array}$ & $\begin{array}{l}1 \\
\mathrm{ND} \\
0 \cdot 04\end{array}$ \\
\hline
\end{tabular}

ND, not done because of plasmid instability.

* Data from three experiments $\pm S D$. Assays were done in the absence of IPTG. XylE activity is expressed in units as described in Methods.

promoter. The results showed that TraK on its own is able to repress both traJp and traKp about 30-fold (Table 5). Similar experiments with ptac-traJ (pJF161n $\Delta 5)$ showed that TraJ can repress traJp fourfold. We were unable to determine the effect of traJ on traKp because the combination of pJF161n $\Delta 5$ and pMZT5 was unstable. A plasmid overproducing TraI is not available due to its lethal effect on the bacterial host (E. Lanka, personal communication). Even attempts to use a plasmid which has a 3 '-truncated version of tral under the control of the tac promoter (pJF166n $\Delta 5$ ) caused problems of instability when introduced into the same cell with promoter probe fusions.

Since $\operatorname{tr} a K$ can act alone to repress $\operatorname{traK} p$ and inactivation of traK in pMS2260 causes complete derepression of traKp, we concluded that TraK is probably the only relaxosome protein which regulates this promoter. For traJp the situation appears to be more complicated since inactivation of $\operatorname{traK}$ in pMS2260 only causes partial derepression. Since traJ under tacp control also causes repression, we concluded that TraJ may be responsible for some of the residual repression by pMS2260 when traK is inactivated, while traI and/or traH may also play a role. Nevertheless TraK once again seems to be the primary repressor protein.

\section{TrbA coordinates expression of both tra and trb operons}

We recently reported that $\operatorname{trf} A p$ and $\operatorname{trbB} p$ are under control of TrbA, encoded by the first ORF in the trb operon and that TrbA may have some special association with control of genes required for conjugative transfer (Jagura-Burdzy et al., 1992). It was therefore of interest to determine whether TrbA also influences transcription from tra promoters. We introduced a plasmid carrying tacp-trb $A$ (pGBT80) in trans to promoter probe vectors carrying promoters traJp, traKp or traGp and determined its effects on expression of the $x y l E$ reporter gene. The results (Table 6) showed that indeed TrbA does give
Table 6. Activity of Tra1 region promoters in the presence of a plasmid overproducing TrbA

\begin{tabular}{|lllll|}
\hline $\begin{array}{l}\text { Plasmid/ } \\
\text { promoter }\end{array}$ & $\begin{array}{c}\text { Plasmid } \\
\text { in trans }\end{array}$ & $\begin{array}{c}\text { RK2 } \\
\text { genes } \\
\text { in trans }\end{array}$ & $\begin{array}{c}\text { XylE } \\
\text { activity* }\end{array}$ & $\begin{array}{c}\text { Relative } \\
\text { activity }\end{array}$ \\
\hline pMZT4/traJp & pGBT30 & None & $10 \cdot 3 \pm 1 \cdot 10$ & 1 \\
& pGBT80 & trb $A$ & $1 \cdot 40 \pm 0.60$ & $0 \cdot 13$ \\
pMZT5/traKp & pGBT30 & None & $9 \cdot 40 \pm 3.90$ & 1 \\
& pGBT80 & trbA & $0.94 \pm 0 \cdot 18$ & $0 \cdot 10$ \\
pMZT6/traGp & pGBT30 & None & $0.40 \pm 0.03$ & 1 \\
& pGBT80 & trb $A$ & $0 \cdot 06 \pm 0.05$ & $0 \cdot 15$ \\
\hline
\end{tabular}

* Data from four experiments $\pm \mathrm{SD}$. Assays were done in the absence of IPTG. XylE activity is expressed in units as described in Methods.

7-10-fold repression of transcription from all the three promoters.

Although these effects of pGBT80 were observed in the absence of IPTG induction and therefore should correspond to only a low level of TrbA expression, the translation of $\operatorname{tr} b A$ has been dramatically improved by the addition of the T7 gene 10 translational signals. To determine whether the unmodified $\operatorname{trb} A$ gene can also have this effect we repeated the assays with TrbA supplied from pVI109.2 (Shingler \& Thomas, 1984a). As a control we used pVI107.2 (Shingler \& Thomas, 1984b) in which the beginning of $\operatorname{trb} A$ is deleted. The results showed that tra $G p$ is repressed fivefold, traJp is repressed fourfold and traKp is repressed two- to threefold. This confirms that an effect of TrbA on Tra1 region promoters is likely to occur in cells carrying the unmodified $\operatorname{trb} A$ gene alone.

\section{Repressors of Tra1 region promoter activities decrease mRNA levels}

To confirm that the repression observed using $x y l E$ as a reporter gene reflected decreased mRNA concentration we performed primer extension on mRNA extracted from bacteria carrying each promoter in the presence of different regulators. The results (Fig. 3) confirmed that for each of the repression activities demonstrated in Tables 5 and 6 , the level of detectable mRNA was decreased proportionately. We noted two anomalous results. First, with traJp the presence of TraJ not only reduces the intensity of the primary transcript but also causes the appearance of a new longer species. The location of the TraJ operator (Fig. 2a), would be consistent with a displacement of RNAP to an upstream position. Second, although TraK repression of traKp resulted in almost complete disappearance of the normal mRNA $5^{\prime}$ end, a new shorter transcript could be detected corresponding to transcription start points shown in Fig. 2(a) (this additional traKp tsp is not shown in Fig. 3). This raises the possibility that TraK represses one promoter but activates a second. However, since reporter gene assays do not detect this putative activation event in the presence of 


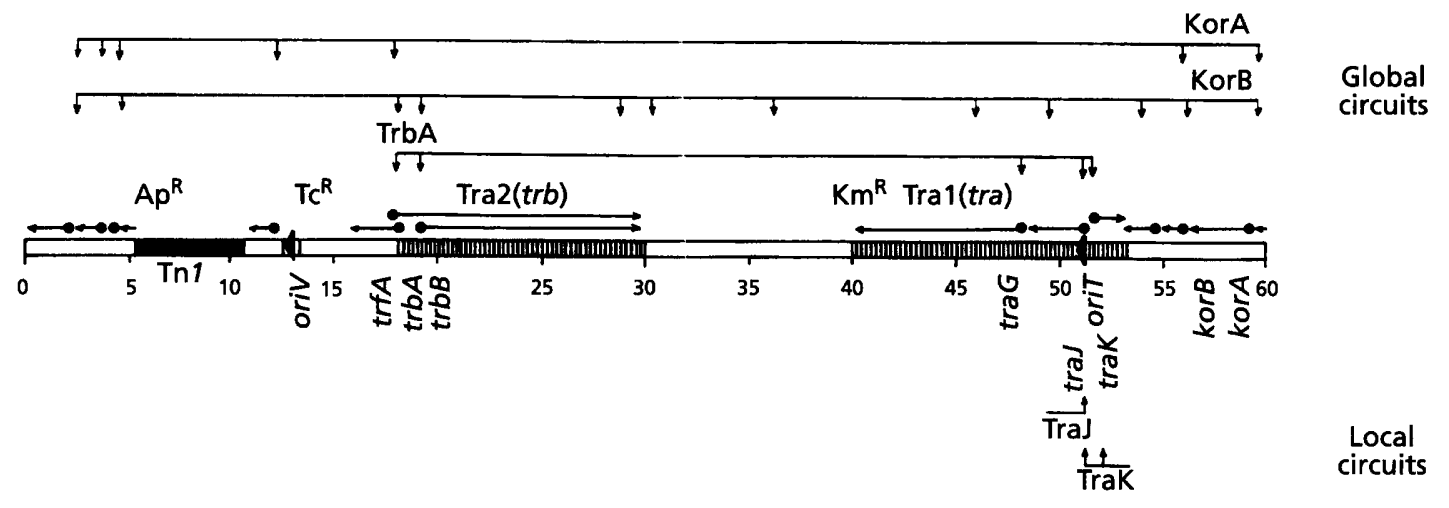

\begin{abstract}
Fig. 4. Summary of control circuits controlling expression of conjugative transfer genes of IncP $\alpha$ plasmids. The key genes are korA, whose product derepresses trbAp activity (Jagura-Burdzy \& Thomas, 1994); korB, whose product represses trbBp (Shingler \& Thomas, 1984a; Motallebi-Veshareh et al., 1992; Thomson et al., 1993) as well as binding to additional operators in the tra and trb regions (Balzer et al., 1992; Williams et al., 1993); and trbA, whose product represses trbBp, traGp, traJp and traKp. KorA represses transcription at all the other places at which it is shown to bind. KorB only represses transcription at the known promoter regions where it binds; many of its binding sites are not near promoters and its effect at these sites is not known.
\end{abstract}

TraK, we do not wish to draw any conclusions based on this observation until further experiments have been carried out.

\section{DISCUSSION}

In this paper we have confirmed the existence of the three promoters $\operatorname{traJ} p, \operatorname{traK} p$ and $\operatorname{tra} G p$ in the Tra1 region. We confirmed the transcription start point for traJp and tra $G p$ as described by Greener et al. (1992), but for traJp we found that there was only a single initiation point. In the case of $\operatorname{traKp}$ we mapped transcription initiation at the GAA residues downstream of the promoter region predicted by Ziegelin et al. (1991).

We have demonstrated that the Tra1 region promoters are not expressed constitutively. traJ $p$ and traKp can be autogenously repressed by their own products: traJp can be repressed about fourfold by TraJ, while traKp can be repressed about 30 -fold by TraK. TraK can also repress traJp about 30-fold (Table 5). The assays in which we used mutants (Table 4) suggest that while traK is the only repressor of $t r a K p$, full repression of traJp requires additional genes since we still observed fourfold repression after inactivation of traK. The small amount of derepression observed with the pMS2260 mutant with an insertion in $\mathrm{traH} / \mathrm{I}$ suggests that these gene(s) may contribute to this residual activity. However, the results obtained with plasmids expressing individual genes suggest that it is TraJ which is the second repressor of traJp. None of the relaxosome proteins affects traGp.

The strongest regulatory effect is caused by the TraK protein which is essential for transfer. Its exact role in transfer is not known, but it increases the yield of relaxed intermediates as a result of relaxosome formation (Fürste et al., 1989). It binds cooperatively to DNA in the oriT region covering about $200 \mathrm{bp}$ (Fig. 2), in which protected and unprotected stretches can be found, and dramatically increases bending of this region. Binding to TraK reduces the apparent length of the oriT fragment in the electron microscope, suggesting that DNA is wound around the protein core of several TraK molecules forming a highly ordered nucleoprotein structure. TraK binding to oriT protects the divergent $t r a J$ and $\operatorname{traK}$ promoter sequences from DNaseI cleavage and hydroxyl radical attack (Ziegelin et al., 1992). Thus, the repression caused by TraK protein is probably the result of exclusion of RNA polymerase from these promoters.

Tra J binding to the right arm of an imperfect $19 \mathrm{bp}$ inverted repeat sequence in the ori $T$ region has been proposed to be the first step in relaxosome formation (Ziegelin et al., 1989). The TraJ-DNA complex is recognized by TraI that nicks the strand to be transferred (Pansegrau et al., 1990). However, TraI itself can cleave specifically in short oligonucleotides spanning oriT (Pansegrau et al., 1993) so the recognition by TraI is not exclusively mediated by the Tra J-oriT complex. Since the binding sites for both Tra J and TraI are located downstream from the transcription start point either protein alone or the complex between the two proteins may prevent RNA polymerase from entering elongation mode after initiation at traJp.

The binding sites for both TraJ and TraK are only found in the oriT region. It was therefore not surprising that they do not affect the activity of $\operatorname{tra} G p$, when it is cloned on its own. However, because no transcriptional terminator was found between tralp and traGp it is conceivable that transcription from both of these promoters normally contributes to expression of $\operatorname{tra} G$ and downstream genes. Ziegelin et al. (1991) observed very low levels of proteins encoded by the genes transcribed from traJp and traKp in cells harbouring these operons in their native configuration. They proposed that this was the result of a very low activity of both promoters. Our data extend this proposal. We showed that not only are 
$\operatorname{traJp}$ and $\operatorname{traK} p$ about one-tenth the strength of the $\operatorname{trf} A$ and $t r b B$ promoters, but in addition they are autoregulated, explaining the very low level of gene expression observed. Ziegelin et al. (1991) also observed that products of the genes downstream of tra $G p$ are present in much higher amounts. However, our results show that $\operatorname{traGp}$ is about 10 times weaker than the oriT promoters which is not consistent with it alone being responsible for the easily visible levels of protein. Transcription from traJp may augment traGp transcription while a mechanism which stabilizes the $\mathrm{mRNA}$ for $\operatorname{tra} G$ and downstream genes could help to boost protein levels from scarce mRNA. Further studies may resolve this point.

All the three promoters studied in this paper were repressed by TrbA, which we showed previously to repress both $\operatorname{trbB} p$ and $\operatorname{trf} A p$ (Jagura-Burdzy et al., 1992). The repression by $\operatorname{TrbA}$ protein is not very strong (about 7-10-fold) in comparison to repression caused by TraK (30-fold) (Tables 5 and 6). It would be interesting to determine whether it has any effect on traJ and traK promoters, when the relaxosome proteins are present.

Our primer extension studies confirmed that the observed repression of our transcriptional reporter genes alters the mRNA level initiated at each promoter. This, together with the presence in the promoter regions of binding sites for the repressors TraK (Ziegelin et al., 1992), TraJ (Pansegrau et al., 1990) and TrbA (M. Zatyka, unpublished) is consistent with the regulation acting at the level of transcription initiation. In Fig. 4 we summarize our current knowledge about regulation of genes in the Tra 1 and $\mathrm{Tr} 2 \mathrm{2}$ regions in the context of the global regulation by Kor $\mathrm{A}$ and $\mathrm{Kor} B$, the products of the central control operon. KorB was shown to repress trbBp (Shingler \& Thomas, 1984a; Motallebi-Veshareh et al., 1992; Thomson et al., 1993). KorA derepresses trb $A p$ activity (Jagura-Burdzy \& Thomas, 1994). The $\operatorname{trb} A$ product seems to be not only a repressor of $\operatorname{trf} A p$ and $\operatorname{tr} p B p$ (Jagura-Burdzy et al., 1992) but also of traJp, traKp and traGp in the Tra1 region, and in this way possibly coordinates Tra1 and Tra2 expression. Furthermore, traJp and traKp are subject to repression by local circuits - TraK represses both traJp and traKp, while traJp seems to be repressed autogenously by its own product.

\section{ACKNOWLEDGEMENTS}

We thank Erich Lanka for provision of plasmids. M. Z. was supported by a Wellcome Trust Project Grant 034605 awarded to C. M. T. and G. J. B. Oligonucleotides were synthesized by AltaBioscience. DNA sequencing was performed on an ABI 373 Automated Sequencer purchased with Wellcome Trust Shared Equipment Grant 038654. The Phosphorimager was purchased with Shared Equipment Grants from the Wellcome Trust (037160) and MRC (G9216078MB).

\section{REFERENCES}

Aiba, H., Adhya, S. \& de Crombrugghe, B. (1981). Evidence for two functional gal promoters in intact Escherichia coli cells. $J$ Biol Chem 256, 11905-11910.
Balzer, D., Ziegelin, G., Pansegrau, W., Kruft, W. \& Lanka, E. (1992). KorB protein of promiscuous plasmid RP4 recognizes inverted repetitions in regions essential for conjugative plasmid transfer. Nucleic Acids Res 20, 1851-1858.

Barth, P. T. (1979). RP4 and R300B as wide host-range plasmid cloning vehicles. In Plasmids of Medical, Environmental and Commercial Importance, pp. 399-410. Edited by K. N. Timmis \& A. Pühler. North Holland: Elsevier.

Birnboim, H. C. \& Doly, J. (1979). A rapid alkaline extraction procedure for screening recombinant plasmid DNA. Nucleic Acids Res 7, 1513-1523.

Bolivar, F., Rodriguez, R. L., Greene, P. J., Betlach, M. C., Heyneker, H. L., Boyer, H. W., Crosa, J. H. \& Falkow, S. (1977). Construction and characterization of new cloning vehicles II. A multipurpose cloning system. Gene 2, 95.

Cole, S. P., Lanka, E. \& Guiney, D. G. (1993). Site-directed mutations in the relaxase operon of RP4. J Bacteriol 175, 4911-4916.

Covarrubias, L. \& Bolivar, F. (1982). Construction and characterization of new cloning vehicles VI. Plasmid pBR329, a new derivative of pBR328 lacking 482 base pairs inverted duplication. Gene 17, 79-89.

Fürste, J. P., Pansegrau, W., Ziegelin, G., Kröger, M. \& Lanka, E. (1989). Conjugative transfer of promiscuous IncP plasmids: interaction of plasmid encoded products with the transfer origin. Proc Natl Acad Sci USA 86, 1771-1775.

Gornall, A. G., Bardwill, C. J. \& David, M. M. (1949). Determination of serum proteins by means of the biuret reaction. $J$ Biol Chem 177, 751-766.

Greener, A., Lehman, S. M. \& Helinski, D. R. (1992). Promoters of the broad host range plasmid RK2: analysis of transcription (initiation) in five species of Gram-negative bacteria. Genetics 130, $27-36$.

Guiney, D. G. \& Lanka, E. (1989). Conjugative transfer of IncP plasmids. In Promiscuous Plasmids of Gram-Negative Bacteria, pp. 27-56. Edited by C. M. Thomas. London: Academic Press.

Heinemann, J. A. \& Sprague, G. F. (1989). Bacterial conjugative plasmids mobilize DNA transfer between bacteria and yeast. Nature 340, 205-209.

Holloway, B. W. \& Richmond, M. H. (1973). R-factors used for genetic studies in strains of Pseudomonas aeruginosa and their origin. Genet Res 21, 103-105.

Jagura-Burdzy, G. \& Thomas, C. M. (1994). KorA protein of promiscuous plasmid RK2 controls a transcriptional switch between divergent operons for plasmid replication and conjugative transfer. Proc Natl Acad Sci USA 91 (in press).

Jagura-Burdzy, G., Ibbotson, J. P. \& Thomas, C. M. (1991). The korF region of broad host range plasmid RK2 encodes two polypeptides with transcriptional repressor activity. J Bacteriol 173, 826-833.

Jagura-Burdzy, G., Khanim, F., Smith, C. A. \& Thomas, C. M. (1992). Crosstalk between plasmid vegetative replication and conjugative transfer: repression of the $\operatorname{trf} A$ operon by $\operatorname{trb} A$ of broad host range plasmid RK2. Nucleic Acids Res 20, 3939-3944.

Kahn, M., Kolter, R., Thomas, C., Figurski, D., Meyer, R., Remaut, E. \& Helinski, D. R. (1979). Plasmid cloning vehicle derived from ColE1, F, R6K and RK2. Methods Enzymol 68, 268-280.

Lanka, E. \& Barth, P. T. (1981). Plasmid RP4 specifies a deoxyribonucleic acid primase involved in its conjugal transfer and maintenance. J Bacteriol 148, 769-781.

Lanka, E., Lurz, R., Kröger, M. \& Fürste, J. P. (1984). Plasmid RP4 encodes two forms of DNA primase. Mol \& Gen Genet 194, 65-72. 
Lessl, M., Balzer, D., Weyrauch, K. \& Lanka, E. (1993). The mating pair formation system of plasmid RP4 defined by RSF1010 mobilization and donor-specific phage propagation. $J$ Bacteriol 175, 6415-6425.

Lessl, M., Balzer, D., Lurz, R., Waters, V., Guiney, D. G. \& Lanka, E. (1992). Dissection of IncP conjugative plasmid transfer: definition of the transfer region Tra2 by mobilization of the Tra1 region in trans. $J$ Bacteriol 174, 2493-2500.

McKenney, K., Shimatake, H., Court, D., Schmeissner, U., Brady, C. \& Rosenberg, M. (1981). A system to study promoter and terminator signals recognized by Escherichia coli RNA polymerase. In Gene Amplification and Analysis, vol. II, pp. 383-415. Edited by J. C. Chirikjian \& T. S. Papas. Amsterdam: Elsevier/North Holland.

Motallebi-Veshareh, M., Balzer, D., Lanka, E., Jagura-Burdzy, G. \& Thomas, C. M. (1992). Conjugative transfer functions of broad host range plasmid RK2 are coregulated with vegetative replication. Mol Microbiol 6, 907-920.

Mullis, K., Falona, F., Scharf, S., Saiki, R., Horn, G. \& Erlich, H. (1986). Specific enzymatic amplification of DNA in vitro: the polymerase chain reaction. Cold Spring Harbor Symp Quant Biol 51, 263-273.

Pansegrau, W., Balzer, D., Kruft, V., Lurz, R. \& Lanka, E. (1990). In vitro assembly of relaxosome at the transfer origin of plasmid RP4. Proc Natl Acad Sci US A 87, 6555-6559.

Pansegrau, W., Schroder, W. \& Lanka, E. (1993). Relaxase (TraI) of IncP plasmid RP4 catalyses a site-specific cleaving-joining reaction of single stranded DNA. Proc Natl Acad Sci USA 90, 2925-2929.

Pansegrau, W., Lanka, E., Barth, P. T., Figurski, D. H., Guiney, D. G., Haas, D., Helinski, D. R., Schwab, H., Stanisich, V. A. \& Thomas, C. M. (1994). Complete nucleotide sequence of Birmingham IncP $\alpha$ plasmids: compilation and comparative analysis. $J$ Mol Biol 239, 623-663.

Sambrook, J., Fritsch, E. F. \& Maniatis, T. (1989). Molecular Cloning: a Laboratory Manual, 2nd edn. Cold Spring Harbor, NY: Cold Spring Harbor Laboratory.

Sanger, F., Nicklen, S. \& Coulson, A. R. (1977). DNA sequencing with chain terminating inhibitors. Proc Natl Acad Sci USA 74, 5463-5467.

Shingler, V. \& Thomas, C. M. (1984a). Transcription in the $\operatorname{trf} A$ region of broad host range plasmid RK2 is regulated by $\operatorname{trf} B$ and korB. Mol \& Gen Genet 195, 523-529.

Shingler, V. \& Thomas, C. M. (1984b). Analysis of $\operatorname{trf} A$ region of broad host range plasmid RK2 by transposon mutagenesis and identification of the polypeptide products. $J$ Mol Biol 175, 229-250.

Sikorski, R. S., Michaud, W., Levin, H. L., Boeke, J. P. \& Hieter, P. (1990). Trans-kingdom promiscuity. Nature 345, 581-582.

Smith, C. A. \& Thomas, C. M. (1983). Deletion mapping of kil and kor functions in the $\operatorname{trf} A$ and $\operatorname{trf} B$ regions of broad host range plasmid RK2. Mol \& Gen Genet 190, 245-254.

Thomas, C. M. (1981). Complementation analysis of replication and maintenance functions of broad host range plasmid RK2 and RP1. Plasmid 5, 277-291.

Thomas, C. M. \& Helinski, D. R. (1989). Vegetative replication and stable inheritance of IncP plasmids. In Promiscuous Plasmids of GramNegative Bacteria, pp. 1-25. Edited by C. M. Thomas. London: Academic Press.

Thomas, C. M. \& Hussain, A. A. K. (1984). The korB gene of broad host range plasmid RK2 is a major copy number control element which may act together with $\operatorname{trf} B$ by limiting $\operatorname{trf} A$ expression. EMBO J 3, 1513-1519.

Thomas, C. M. \& Smith, C. A. (1987). Incompatibility group P plasmids: genetics, evolution and use in genetic manipulation. Annu Rev Microbiol 41, 77-101.

Thomson, V. J., Jovanovic, O. S., Pohlman, R. F., Chang, C.-H. \& Figurski, D. H. (1992). Structure, function and regulation of the kilB locus of promiscuous plasmid RK2.J Bacteriol 175, 2423-2435.

Trieu-Cuot, P., Carlier, C., Martin, P. \& Courvalin, P. (1987). Plasmid transfer by conjugation from Escherichia coli to Grampositive bacteria. FEMS Microbiol Lett 48, 289-294.

Williams, D. R., Young, D. I. \& Young, M. (1990). Conjugative plasmid transfer from Escherichia coli to Clostridium acetobutylicum. J Gen Microbiol 136, 819-826.

Williams, D. R., Motallebi-Veshareh, M. \& Thomas, C. M. (1993). Multifunctional repressor KorB can block transcription by preventing isomerization of RNA polymerase-promoter complexes. Nucleic Acids Res 21, 1141-1148.

Winans, S. C. \& Walker, G. C. (1985). Fertility inhibition of RP1 by IncN plasmid pKM101. J Bacteriol 161, 425-427.

Ziegelin, G., Fürste, J. P. \& Lanka, E. (1989). Tra J protein of plasmid RP4 binds to a 19 base pair invert sequence repetition within the transfer origin. J Biol Chem 264, 11989-11994.

Ziegelin, G., Pansegrau, W., Strack, B., Balzer, D., Kröger, M., Kruft, V. \& Lanka, E. (1991). Nucleotide sequence and organization of genes flanking the transfer origin of promiscuous plasmid RP4. $D N A$ Sequence 1, 303-327.

Ziegelin, G., Pansegrau, W., Lurz, R. \& Lanka, E. (1992). TraK protein of conjugative plasmid RP4 forms a specialized nucleoprotein complex with the transfer origin. $J$ Biol Chem 267, 17279-17286.

Zukowski, M. M., Gaffney, D. F., Speck, D., Kauffman, M., Findeli, A., Wisecup, A. \& Lecocq, J.-P. (1983). Chromogenic identification of genetic regulatory signals in Bacillus subtilis based on expression of a cloned Pseudomonas gene. Proc Natl Acad Sci USA 80, 1101-1105.

Received 21 April 1994; revised 15 July 1994; accepted 20 July 1994. 